\title{
On the Analogy Between the Electric Grid and Our Banking System: Investigating "Consumer Power" in Deregulated Power Markets
}

\section{Per Ribbing}

Department of Engineering Sciences, Division of Electricity, Uppsala University, Uppsala, SE-751 05, Sweden

\section{Abstract}

This article investigates the Product Electricity, the product being sold at our power markets and distributed via our electric grids. The paper aims to enhance the understanding of the physics behind the Product Electricity. The traditional (physical) perspective of the purchase of power might have been compromised already in the early 1900's. This investigation aims to clarify what electric power really is, how it is traded, and if the different offers of so called 'Green Power' are valid.

A deregulated power market is ruled by the laws of the free-market, i.e. Supply and Demand. It is not ruled by the laws of Ohm and Kirchhoff. To purchase the Product Electricity is to place an order of consumption beforehand, not specified in volume, space or time. The economical transaction; purchasing electric power, is strictly non-physical.

Today, an active choice of not buying fossil power is advertised on the power markets. Customers who do not want to get electricity generated from fossil fuels are offered to stop buying it. This article tries to answer the question if that offer is valid.

\section{Introduction}

One form of energy, often converted from the burning of fossil fuels, is electric energy i.e. electricity. This paper takes a closer look at the Product Electricity in deregulated electricity markets. The deregulated electricity market in the Nordic countries + the Baltic states (Nord Pool) today offers the possibility of active choices by consumers; 'Consumer Power' if you like.

\section{Publication History:}

Received: July 09, 2018

Accepted: August 02, 2018

Published: August 13, 2018

\section{Keywords:}

Green Power, Consumer Power, Renewable energy, Energy efficiency, Paradigm shift

\section{BANK GRID POWER GRID}

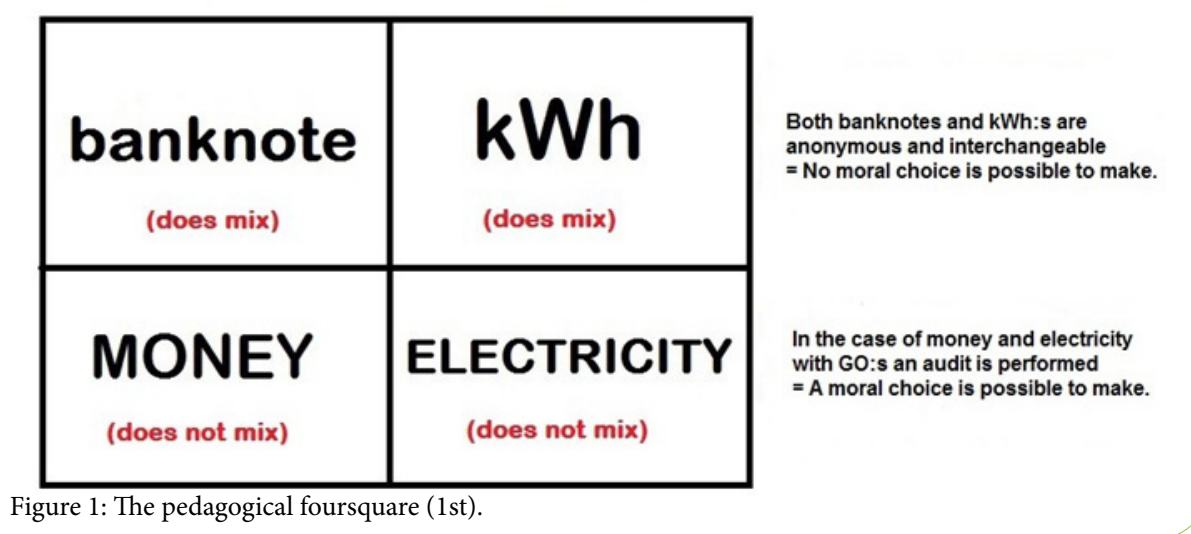

Global Warming as an adverse effect from burning of fossil fuels, described already by Svante Arrhenius in his 1896 article: "On the Influence of Carbonic Acid in the Air upon the Temperature of the Ground" [1], is now a global concern. Different labels of different kinds of electricity exists, not only in the Nordic countries but all over Europe and North America. However, quite a few questions have been raised, in media as well as in academic papers, over the possibility of separating different kinds of power (e.g. wave, wind, solar, hydro, bio or nuclear) and selling it (sending it) to specified customers.

\section{Is that really possible?}

To be able to answer that question we need to investigate the Product Electricity, the product being sold in our power markets and distributed in our electric grids. Doing so, an analogy with our banking system is investigated. The banking system is a system we know very well and use as often as our energy system, i.e. daily. In the banking system we separate the words "Money" and "Banknote" and handle them separately (Figure 1). Never did we question that the Banknotes we withdrew from our account was our money. We know that there is an audit made, an audit that would never allow us to withdraw more money from our account than we have deposited and we know that we could never withdraw any other person's money, only our own, previously deposited, money. This is clear. Even though we never, with any certainty, can tell from where the physical banknotes came.

Corresponding Author: Sir Per Ribbing, Department of Engineering Sciences, Division of Electricity, Uppsala University, Uppsala, SE-751 05, Sweden; E-mail: per.ribbing@angstrom.uu.se

Citation: Ribbing P (2018) On the Analogy Between the Electric Grid and Our Banking System:Investigating "Consumer Power" in Deregulated Power Markets. Int J Earth Environ Sci 3: 154. doi: https://doi.org/10.15344/2456-351X/2018/154

Copyright: @ 2018 Ribbing. This is an open-access article distributed under the terms of the Creative Commons Attribution License, which permits unrestricted use, distribution, and reproduction in any medium, provided the original author and source are credited. 
Citation: Ribbing P (2018) On the Analogy Between the Electric Grid and Our Banking System:Investigating "Consumer Power" in Deregulated Power Markets. Int J Earth Environ Sci 3: 154. doi: https://doi.org/10.15344/2456-351X/2018/154

Page 2 of 10

However, how we view the Product Electricity is not clear. After studying almost 100 peer reviewed scientific articles a questionable level of understanding of what electric power really is, was detected. Therefore this article first states the fundamental physics of power production.

\section{Fundamental physics}

Electric power has to be consumed the very same instant it is produced, and vice versa. Electricity itself cannot be stored. However, it could be converted into chemical potential energy and stored in a battery, or it could be converted into hydrogen gas and stored in a $\mathrm{H}_{2}$ storage, e.g. Also, water can be stored in dams at hydropower stations, storing a potential energy later to be converted into electric power This can be done by saving water in the hydropower dam by reducing the flow through the turbines. This is normally the case when e.g. wind power production is high. Or, water can also be stored at times of low demand, often at night, in so called pumped-storage hydropower. But electricity, in itself, cannot be stored. That's fundamental physics, not commonly known by the majority of power consumers.

Power production must, at all times, be equal to power consumption:

$$
\sum \mathrm{P}=0 \quad\left(\mathrm{P}_{\text {produced }}-\mathrm{P}_{\text {consumed }}=0\right)
$$

This follows both from the first law of Thermodynamics (Equation 2) and Kirchhoff's Current Law (Equation 3).

$\mathrm{W}_{0}=\mathrm{W}_{1} \quad$ Energy is always preserved

$\Sigma \mathrm{I}=0 \quad$ The sum of currents flowing into and out of a node always equal zero

Electric power is an electromagnetic wave travelling at the speed of light through a conductor with free charges, in the normal case: electrons. The more free charges (electrons) there are the less resistance and therefore less heat loss, there is. The electric power is the electromagnetic wave. Not the electrons.

\section{$\mathrm{P}=\mathrm{V} \cdot \mathrm{I} \quad$ Electric Power $(\mathrm{P})$ equals the product of Voltage $(\mathrm{V})$} and Current (I)

$\mathrm{W}_{\mathrm{el}}=\mathrm{P} \cdot \mathrm{t}$ Electric Energy $\left(\mathrm{W}_{\mathrm{el}}\right)$ equals the product of Power $(\mathrm{P})$ and time $(\mathrm{t})$

The SI unit for electric energy is Joule $(\mathrm{J}): 1 \mathrm{~J}=1 \mathrm{Ws}$, but electricity is bought and sold in kilowatt-hours $(\mathrm{kWh})$ where $1 \mathrm{kWh}=3600$ MJ. You cannot determine (downstream) how a specific kWh was produced (upstream), but you can audit how a kWh was produced (upstream).

\section{Energy storage and power regulation}

As Equations 1, 2 and 3 all state there must always, at every second, be a balance in the power system, a balance between power production and power consumption. A measure of imbalance between production and consumption is the grid frequency, $f[\mathrm{~Hz}]$.

If power production $>$ power consumption the grid frequency increases so that power production $=$ power consumption (i.e. energy is stored as kinetic energy in the rotating mass of the generators in the system, hence they speed up).

If $\mathrm{P}_{\text {produced }}>\mathrm{P}_{\text {consumed }}=>f$ increases until $\mathrm{P}_{\text {produced }}=\mathrm{P}_{\text {consumed }}$

If power production < power consumption the grid frequency decreases so that power production $=$ power consumption (i.e. kinetic energy is released from the rotating mass of the generators in the system, hence they slow down).

$$
\text { If } \mathrm{P}_{\text {produced }}<\mathrm{P}_{\text {consumed }}=>f \text { decreases until } \mathrm{P}_{\text {produced }}=\mathrm{P}_{\text {consumed }}
$$

The grid frequency is monitored and kept within limits 49,90-50,10 $\mathrm{Hz}$ by Svenska Kraftnät (Swedish National Grid) at all times. Two fundamental parameters must be kept under close control; Power and Energy. The task of keeping the power balance: $\mathrm{P}_{\text {produced }}-\mathrm{P}_{\text {consumed }}=0$ (Equation 1) becomes slightly more difficult when more intermittent sources of energy is added to the system, e.g. solar PV and wind power. Both these sources are intermittent. Hence, the energy storage facilities in the system are crucial for a secure supply of power. Earlier studies has shown that the existing hydropower in Sweden has the capacity to regulate at least $11.000 \mathrm{MW}(11 \mathrm{GW})$ of installed wind power [2] and that a $100 \%$ renewable power system in Sweden is possible [3].

\section{Fundamental Economics}

It's obvious that it is crucial to separate physics and economy in this matter. On a market the customer is king. A product that doesn't find any buyers will not stay on the market. In a deregulated electricity market the customers are offered a choice of what kind of power they want to buy. Power that no one buys will not be produced. E.g. no one will burn coal in a coal power plant unless they are paid to do it.

\section{Different forms of electric power}

The Product Electricity comes in many different environmental qualities. Only one (1) kind of the Product Electricity on the Swedish market contains electricity generated from fossil fuels (coal, oil, gas) (Figure 2). That is the Nordic Residual Mix (NRM) ${ }^{1}$. NRM is unspecified electricity, so ceasing to buy unspecified electricity (electricity without Guarantees of Origin) is in fact a cessation of buying fossil power. How do we know this? Through auditing! NRM is electricity that is unspecified upstream. The other alternatives are not, because they are all audited and sold with their Guarantees of

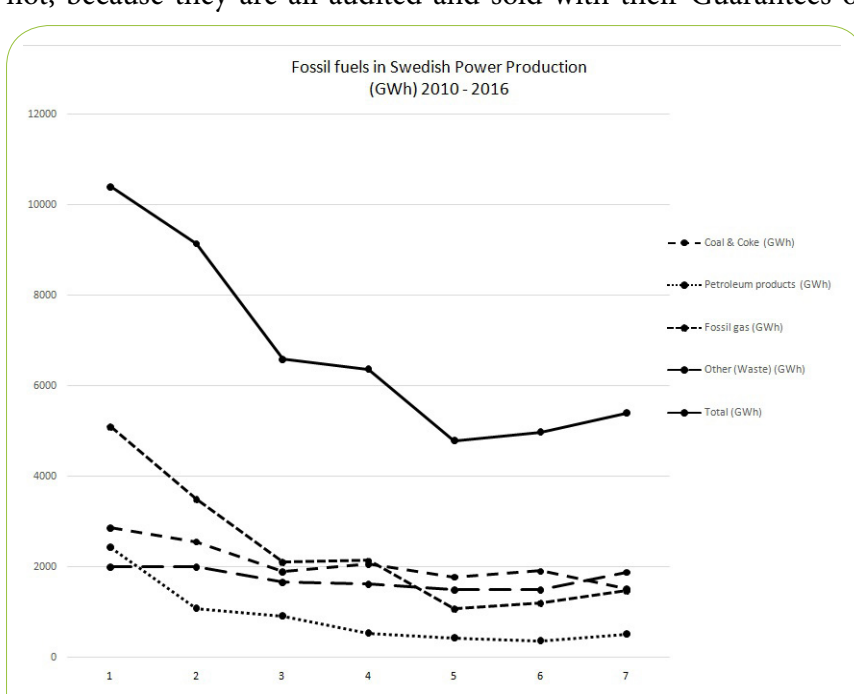

Figure 2: Fossil fuels in swedish power production. 
Citation: Ribbing P (2018) On the Analogy Between the Electric Grid and Our Banking System:Investigating "Consumer Power" in Deregulated Power Markets. Int J Earth Environ Sci 3: 154. doi: https://doi.org/10.15344/2456-351X/2018/154

Page 3 of 10

Origin intact. It is not at all complicated to ascertain that a utility company that markets itself as only selling "Green Power", in fact does not purchase and sell any other kind of power.

In Sweden, especially, consumers do not speak about the fact that we $\boldsymbol{d o}$ have fossil fuels involved in Swedish power production ${ }^{2}$ (Table 1) [4].

\begin{tabular}{|c|c|c|c|c|c|}
\hline $\begin{array}{l}\text { Fuel: } \\
\text { Year }\end{array}$ & $\begin{array}{l}\text { Coal } \\
\& \\
\text { Coke }\end{array}$ & $\begin{array}{l}\text { Petroleum } \\
\text { products }\end{array}$ & $\begin{array}{l}\text { Fossil } \\
\text { Gas }\end{array}$ & $\begin{array}{l}\text { Other } \\
\text { (Waste) }\end{array}$ & $\begin{array}{l}\text { Total } \\
(\text { GWh })\end{array}$ \\
\hline 2010 & 2864 & 2435 & 5097 & 1993 & 10396 \\
\hline 2011 & 2555 & 1094 & 3493 & 1999 & 9141 \\
\hline 2012 & 1897 & 922 & 2104 & 1665 & 6588 \\
\hline 2013 & 2063 & 540 & 2141 & 1628 & 6372 \\
\hline 2014 & 1780 & 437 & 1076 & 1497 & 4790 \\
\hline 2015 & 1911 & 372 & 1199 & 1506 & 4988 \\
\hline 2016 & 1518 & 524 & 1481 & 1883 & 5406 \\
\hline
\end{tabular}

Table 1: Fossil fuels consumed in Swedish power production.

\section{Trading at Nord Pool}

Besides Sweden all other countries (except Norway) trading electricity at the power exchange Nord Pool Spot, have a much larger share of fossil fuels in their electric power production.

If no one bought fossil electricity all fossil power plants would eventually have to be phased out. This conclusion can be drawn from a simple fundamental principle of economics: a product that no one buys, no one will produce. That's just as true regarding electric power production as any other product. The general confusion regards this specific question: How do I know I don't get any fossil power? "By auditing" is the simple answer.

\section{Auditing by the EU system: REDISS - Reliable Disclosure Systems for Europe}

There still is a very low percentage of customers making an active choice when buying electric power, though declared preferences suggest otherwise. The reason for this could be the common misunderstanding concerning the purchase of the Product Electricity. The common misunderstanding states that "all power mixes on the grid, hence it's impossible to choose what power you buy". This common misunderstanding has even led the Norwegian Consumer Authority to rule marketing of "Green Power" illegal 3 and the Nordic Ecolabel to omit criteria concerning what power their licensees must buy. Today it is possible to market e.g. a hotel with the Nordic Ecolabel even if they buy fossil power ${ }^{4}$.

Very few people in Sweden want to pay for power generated from fossil fuels [5]. This is also true in many other countries [6,7,8,22,23]. In fact, nowhere have I found any preferences to buy fossil power.

'https://www.ei.se/en/

2http://www.energimyndigheten.se/statistik/energilaget/

${ }^{3} \mathrm{https} / / / \mathrm{www}$.forbrukertilsynet.no/english

${ }^{4} \mathrm{http}: / /$ www.svanen.se/en/

Int J Earth Environ Sci

ISSN: $2456-351 \mathrm{X}$
And that I say after over 20 professional years in the energy and power sector. I conclude that a majority of customers would stop buying fossil power if they knew they had that choice. Additionally, a reduced demand for fossil power also implies increased investments in energy efficiency and more investments in renewable power production.

My studies, conducted over a more than 20 year long period (since 1997), show that the possibility to single out, and stop buying, power produced from fossil fuels is something consumers definitely do demand. Actually, today, to a large extent, consumers already have this possibility but the general confusion over the physics of power production and distribution, coupled with very little knowledge of how the trading of electricity is done, has resulted in very few active choices of what electricity people buy. Also, there is very little knowledge about the EU auditing system; REDISS (http://www. reliable-disclosure.org/) where the audit of Guarantees of Origin (GO:s) ensure customers that double-selling of "Green Power" is impossible.

\section{Definition of the economic entity: the Product Electricity}

Buying electricity is quite different from purchasing any other product. Buying the Product Electricity is actually placing an order, beforehand, of kilowatt-hours to be produced. The annual purchased volume is estimated from last year's consumption. The purchased electricity could be consumed at any time and at any geographical location where the consumer is identified and the consumed product is metered. To clarify, I use the case of charging an electric vehicle. An electric vehicle can be charged at many different geographical locations, any day and time of day. If the charged volume of kilowatthours is metered and the consumer is identified (e.g. starting the charging with an RFID-tag or Smartphone) then the purchased volume of the Product Electricity could be added to the identified consumer's electricity bill. The consumer does not know how many $\mathrm{kWh}$ will be consumed during a year (how many electric kilometers will be driven). The Product Electricity is balanced over a year and there is a balancing done at the end of the year where the actual consumption is revised versus the anticipated and the difference is billed, or deducted, on the next bill.

\section{Definition of the physical entity: the kilowatt-hour (kWh)}

An electric vehicle can be charged with a number of different plugs and outlets, at different levels of power, some cars with both AC- and DC-charging. The consumer, of course, does not know which physical kilowatt-hours (upstream) are consumed during charging but the specified Product Electricity (downstream) comes with Guarantees of Origin that are cancelled in the same amount as the kilowatt-hours being charged. The REDISS auditing system guarantees traceability of the purchased Product Electricity. Hence, there is no risk of involuntarily charging your battery electric vehicle (BEV) with fossil power.

\section{Historic explanation}

Looking at the history of the development of a nationwide electric grid in Sweden can give an explanation as to why the traditional perspective of purchasing the Product Electricity is still perceived as valid. Scientific articles in this matter have been hard to find, see e.g. David L. Morton [9]. 
Citation: Ribbing P (2018) On the Analogy Between the Electric Grid and Our Banking System:Investigating "Consumer Power" in Deregulated Power Markets. Int J Earth Environ Sci 3: 154. doi: https://doi.org/10.15344/2456-351X/2018/154

Page 4 of 10

Picture the case of a single generator, e.g. a hydropower station (A) in the early 1900's, powering a local grid ( $\alpha$ ). In another location a similar hydropower station (B) powers another local grid $(\beta)$. The consumed Product Electricity was in this original configuration the exact same as the physical kWh consumed. No audit was performed. It was not needed. Metering of consumed kWh:s was sufficient since the physical entity (the kWh) was identical to the economic entity (the Product Electricity). But as soon as the grids $\alpha$ and $\beta$ were interconnected $(\alpha+\beta)$ there was no way of telling from which hydropower station the physical kWh the different customers received (downstream). Still, the metering of consumed $\mathrm{kWh}: \mathrm{s}$ was the only data needed since the customers continued paying the power bill to the same power company (A or B) that the customer "belonged to", meaning which grid they were getting their electricity from: grid $\alpha$ or grid $\beta$. The Swedish power grid developed into a nationwide power grid and then developed even further as the Swedish grid got connected to the grids of Denmark, Norway and Finland, and now, as of lately, to the power grids of the Baltic states. In Sweden the electricity market was regulated in geographical monopolies (grid monopolies) up until 1 January 1996 [10]. Before that date consumers could not make any active choice concerning what power to buy. During the monopoly the view of the Product Electricity was the physical one, where the currents of electricity "flows" and mixes like currents of water. This view of the Product Electricity stayed on even after the deregulation, and that view has unfortunately stuck with the majority of both consumers and producers. This paper aims to modernize this view and bring it into the 21 st century.

\section{REDISS, Auditing Consumption vs Production with Guarantees of Origin}

The Swedish power grid is interconnected with the power grids of all our neighboring countries and the Nordic region is connected to the rest of Europe. In 2020, Norway will have a direct $1400 \mathrm{MW}$ HVDC-connection to England [11]. The cable will run from Kvilldal, Suldal in Norway, to Blyth in the United Kingdom. The NSN Link (North Sea Network) will be a part of the North Seas Countries Offshore Grid Initiative (NSCOGI) which integrates offshore wind farms and other renewable energy sources across the northern seas of Europe. The Swedish NordBalt 700 MW HVDC, connecting Sweden and Lithuania, went on-line in the beginning of 2016 [5].

The power market is ruled by the normal laws of free-market economy; the laws of Supply and Demand [12]. The power market is not ruled by the laws of Ohm and Kirchhoff $[13,14]$. The electric grid, and the production and consumption of electric power, is ruled by the fundamental laws discovered by Georg Simon $\mathrm{Ohm}^{6}$ and Gustav Kirchhoff $^{7}$ - but not the power market itself. It is absolutely crucial not to mix physics and economics to properly understand this new perspective, and the possibility it presents to help develop a fossil-free energy system.

In this paper I suggest that utilities, policy makers and society as a whole start using a new and different perspective on the Product Electricity, a strictly economical, non-physical perspective. Using this perspective, the market would open up possibilities for consumers, large and small, to effectively execute their 'Consumer Power' on the Nord Pool electricity market. I also make a suggestion to the European Union, to their REDISS system, below ${ }^{8}$.

${ }^{5}$ https://www.svk.se/en/grid-development/grid-projects/nordbalt1/

${ }^{6} \mathrm{http}: / /$ global.britannica.com/biography/Georg-Simon-Ohm

7http://www.newworldencyclopedia.org/entry/Gustav_Kirchhoff
This new economic perspective on the Product Electricity also reveals that consumers indeed do have the possibility to stop buying electric power generated from fossil fuels already today. Hence, the proposed new perspective gives the consumers the possibility to have an impact on the flows of (investment) capital. Of course, the consumers have no impact of the physical flows of the produced electromagnetic fields (this is self-evident [14]) but since it is the currents of money that develop the energy system and not the currents of electrons this is not a point to get stuck on. Now, obviously, the demand for an audit becomes inevitable. It mustn't be possible for a utility to sell more of a specific Product Electricity than they have produced (or purchased from another producer). An audit to prevent "double-selling" must be performed. This is exactly what the EU-system REDISS does; Reliable Disclosure Systems for Europe ${ }^{9}$. With the new perspective it is evident that the customers of an electric utility company have the opportunity to stop buying fossil power simply because the consumer can actually buy the specified power he or she wants.

\section{The traditional perspective}

The traditional perception of how electricity is purchased and consumed can be exemplified by quoting a large number of the reviewed papers, e.g. Hansla et al: [15]

"When supplied to a home it is not possible for the household consumer to know how the electricity was produced."

How the historical view of electricity perceives the Product Electricity as something that is delivered (physically) can be described by quoting Hauch: [16]

"In Norway, $\mathrm{CO}_{2}$ emissions can be reduced only by substitution in households and in other productions sectors than electricity."

Actually, in Norway most of the Guarantees of Origin in the REDISS-system are sold abroad so that only $15 \%$ of the "green value" is left in Norway ${ }^{10}$. The system of selling the "green attributes" (the Guarantees of Origin) separate from the Product Electricity creates a misunderstanding. The general public in Norway think they are consuming almost $100 \%$ hydropower but they are actually consuming the Nordic Residual Mix (Figure 3) which contains both fossil electricity (42.77\%) and nuclear power (40.55\%). Only $16.68 \%$ of the Nordic Residual Mix 2017 was renewable power ${ }^{11}$. This Residual Mix is calculated by the Swedish Energy Markets Inspectorate (www. ei.se) each year after cancellation of the traded Guarantees of Origin.

\section{The new perspective}

Contrary to the traditional view I propose a different definition of the Product Electricity. The proposed definition of the Product Electricity is the specified product the customer chooses to buy, according to the contract with their utility. The physical delivery of said product is made by anonymous kilowatt-hours who are carriers of the value produced, the value not only being electric energy but also environmental values.

${ }^{8}$ Suggestion: do not allow Guarantees of Origin to be sold separate from the power. The GO should never be separated from the Product Electricity sold as "green". This way fossil power could never be sold (with acquired GO:s) under the false pretense of being "green" or anything else. This is possible today only because GO:s are allowed to be traded separate from the power itself.

${ }^{9}$ http://www.reliable-disclosure.org/upload/65-RE-DISS_2013_Residual_Mix_Results_ v1-0_2014-05-15.pdf

${ }^{10} \mathrm{http}: / /$ www.nve.no/en/Electricity-market/Sluttbrukermarkedet/Varedeklarasjon/New calculation-method-for-disclosure-in-Norway/

${ }^{11}$ https://www.ei.se/sv/for-energiforetag/el/ursprungsmarkning-av-el/ 


\section{Nordic Residual Mix 2017}

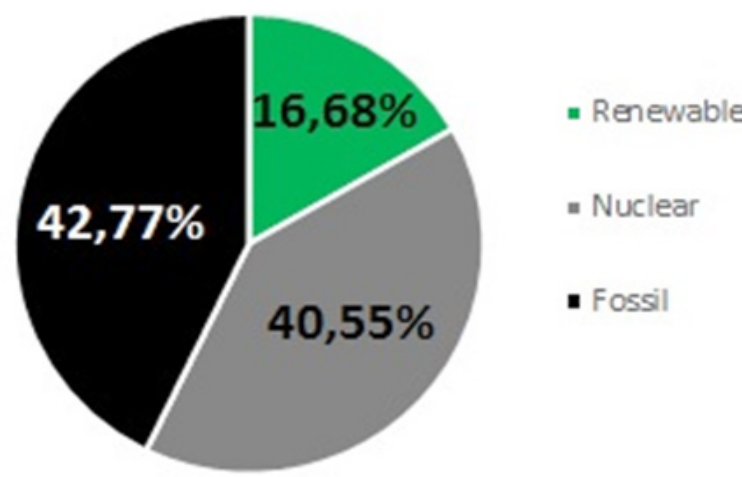

Figure 3: Nordic Residual Mix 2017.

\section{Methods}

An extensive review of scientific articles covering the subject has been made. All of the studied articles have been written in the traditional, physical perspective as exemplified above, and below. The proposed new perspective on the Product Electricity in a deregulated market is presented and elaborated on.

\section{The physical perspective}

The traditional perspective on electricity as a product that cannot be traced applies for all consumers of the Product Electricity from a shared grid, big or small, public or private, homes or industries. Let the traditional perspective be named the "Physical Perspective", where essentially currents of electricity are looked upon as currents of water, all being mixed on the electric grid. In the Physical Perspective this description by Wüstenhagen and Bilharz [17] holds true:

"Unlike in the case of buying organic food or other green products, a green power customer does not get a physically different product, but the difference lies in monetary flows. If products are designed properly - i.e. double-selling is avoided - the purchasing decisions of green customers will translate into a change in the electricity mix."

However, in the new perspective, defined below, that description is a misconception.

When Swedish Society for Nature Conservation introduced criteria for Eco labeled electricity in January 1996 [18] articles in press and media, e.g. the largest Swedish newspaper, Dagens Nyheter, in different ways mocked and scorned the idea of Eco labeled electricity. "It's just a scam" was their message, since all electricity was mixed". That was the logical reasoning following the traditional perspective. Contrarily, with the new perspective, consumers have a real, de facto, choice of what power they buy and consume.

In the Physical Perspective, the electromagnetic fields on the grid are perceived as currents of water in a pipeline system. In this perspective all different kinds of electricity are mixed on the grid. A common picture describing this traditional perspective is a bathtub into which electricity from different power plants is "poured" hence the Physical Perspective is also referred to as "the Bathtub Model" (Figure 4) by most people in the trade.

${ }^{12}$ Claes Göran Kjellander, Dagens Nyheter 1996-01-17 "Konsten att tjäna gröna kronor"
Into the bathtub green, blue, grey or black electricity is supplied. Let green stand for new renewable electricity such as wind, wave, solar and marine current power. Let blue stand for existing hydropower, grey for nuclear power and black for electricity produced from fossil energy such as coal, oil and gas.

\section{Apparent lack of logic of the physical perspective}

Before 1996 the Swedish electricity market was essentially a monopoly. Customers had to buy their electricity from the utility running the electric grid in their area. Looking at the Product Electricity with the Physical Perspective the customer had the same mixed electricity then as after the deregulation. If, as the Physical Perspective states, electricity is to be considered parallel to water flowing (and mixing) on the grid there was no way of knowing what electricity a specific consumer got. Nevertheless, people paid their power bills to their utility not posing any arguments as to what electricity (from whose production) they were actually receiving. Questions of whose electricity a specified customer received became common only after the deregulation of the electricity market. This is inconsistent since the grid was not altered, in any way, by the deregulation of the market.

Furthermore, what kWh is physically consumed is non-significant from a market point of view. Contrary to common perception it is of no significance what actual product the consumer physically consumes after executing his/her 'Consumer Power'. E.g. a man buying organic bananas in the store is executing his 'Consumer Power'. If he later on trades the organic bananas with his neighbor's conventionally produced bananas and consumes those bananas instead, he still has had an impact on the market of bananas. 'Consumer Power' is executed in the purchasing moment, not in the consuming moment. Indeed, a parallel with the product discussed here: the Product Electricity.

\section{The new perspective: the Bank Parallel}

To explain the new perspective an analogy is introduced; an analogy with a very well-known system that everyone uses practically every day; the Banking System: The banking system uses anonymous agents of money, e.g. banknotes, to transfer money from a client's account to the client. In an Automatic Teller Machine (ATM) the banknote at the very top of the stack inside the machine can either be person A's, if A precedes B in line, or B's, if A lets B precede him. However, the fact that the banknote at the top of the stack can either become A's or B's (the banknote itself is interchangeable), does not make A's and B's money interchangeable. Hence, the banknote itself is an anonymous agent of the money in said persons account.

Nota bene: The word "money" is noted different from the word "banknote".

In just the same manner the power system uses anonymous agents of the Product Electricity; e.g. kilowatt-hours (or Joules, $1 \mathrm{kWh}=3.6$ $\mathrm{MJ})$. If person A turns on his electric kettle before person B, A gets the first Joule waiting in line to be produced (and instantly consumed) from the electric grid while if person $B$ turns on his electric kettle before person A, B gets that very same Joule. However, the fact that the next electric Joule produced (and instantly consumed) can either become A's or B's (the Joule itself is interchangeable) does not make A's and B's electricity interchangeable. Hence, the Joule (or kWh) itself is an anonymous agent of the Product Electricity bought by person $\mathrm{A}$ and person $\mathrm{B}$ and is measured and deducted from said persons individual "electricity account". 


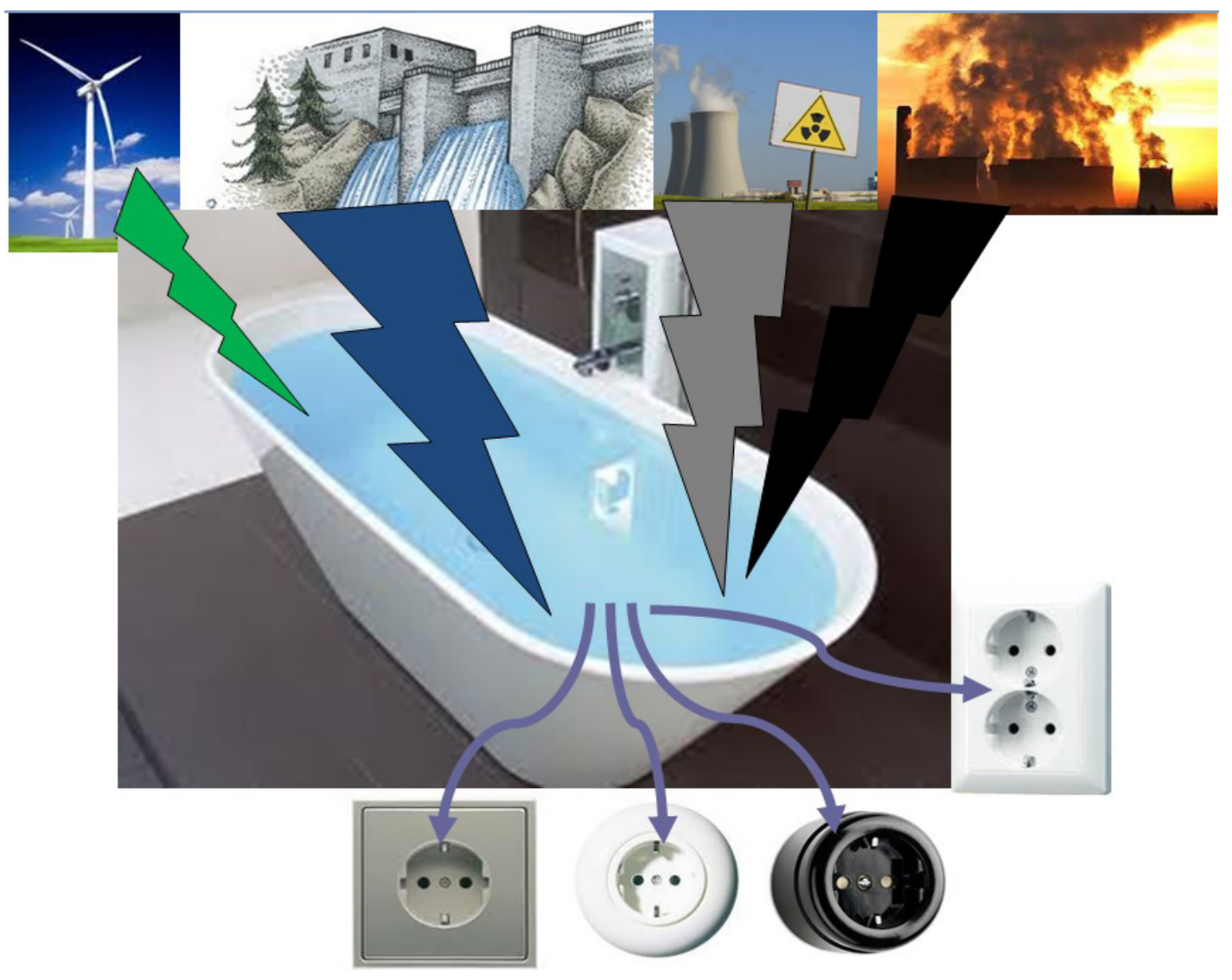

Figure 4: The Bathtub Model.

Nota bene: The word "electricity" is noted different from the word " $k W h$ ".

In fact, the new perspective was valid even during the time of the old power monopoly because if the Physical Perspective had been correct the consumer could never have known what power plant their kWh came from, hence they would not have known which utility company they should have paid their electricity bill to. Consequently, the Physical Perspective appears inconsistent to apply in any deregulated market. According to the traditional logic of the Physical Perspective each power producer would need to supply their electricity in separate electric grids which of course would be practically and economically unfeasible.

The new perspective might be conceived as somewhat abstract but the analogy with banknotes and money aims at making this easy to understand and accept. It's a way of communicating with the public. Most people do not have the necessary knowledge in fundamental physics to understand why electric power must be produced and consumed at the same instant. As a parallel, people have very little knowledge in the production of banknotes. Still no one ever wonders if the banknotes they withdraw from their account is, in fact, their money. They know that it is their money, no matter what banknotes they physically receive in their hand. They know you can only withdraw from your account the very same money previously deposited there. Not any other money, just other banknotes. Hence, let this new perspective be called the Banking Paradigm.

\section{Physical property of electric power and grid stability}

One fundamental physical property of electric power is that power cannot be produced unless it is consumed at the same time, instantly. To keep a grid prompted with the possible production of electric power, with a stable frequency and voltage (e.g. $230 \mathrm{~V}, 50 \mathrm{~Hz}$ ), and also allow large variations in consumption, is the engineering feat of the grid operators. It appears, in our proposed parallel with the banking system, equal to keeping all ATM's stacked with enough banknotes to allow a large variation in withdrawals. Some hours there will be large withdrawals, some hours only small withdrawals, or even none at all. But there must always be a stack of banknotes in the ATM. That's the analogy for grid stability ${ }^{13}$. The cost for keeping the grid stable, which safeguards society from black-outs, is paid by the consumers. What extra costs might arise, if any, when old fossil power generators are replaced by new power plants, or energy efficiency is enhanced in the system, is hard to foresee. Future evaluation will be of great interest, not only from an economical point of view.

\section{Different products, different kinds of electricity}

The parallel between the Product Electricity and money, as well as the parallel between anonymous $\mathrm{kWh}$ and anonymous banknotes, explains that a person buying a specified kind of electricity receives that product, no other. The purchased electricity is delivered by anonymous agents, kilowatt-hours, who are deducted from the consumer's individual "electricity account". The European system for ${ }^{13}$ See section 1.1.1 - If $\mathrm{P}_{\text {produced }}<\mathrm{P}_{\text {consumed }} \Rightarrow>f$ decreases until $\mathrm{P}_{\text {produced }}=\mathrm{P}_{\text {consume }}$
and If $\mathrm{P}_{\text {produced }}>\mathrm{P}_{\text {consumed }}=>f$ increases until $\mathrm{P}_{\text {produced }}=\mathrm{P}_{\text {consumed }}$ 
Citation: Ribbing P (2018) On the Analogy Between the Electric Grid and Our Banking System:Investigating "Consumer Power" in Deregulated Power Markets. Int J Earth Environ Sci 3: 154. doi: https://doi.org/10.15344/2456-351X/2018/154

Page 7 of 10

Reliable Disclosure (REDISS) and its GO:s (Guarantees of Origin) ensures the power consumers that they get the Product Electricity they buy and no other. The criteria can be as simple as "non-fossil electricity" not having any further environmental limitations. Criteria could also be technically specific such as "solar power", sold by e.g. Telge Energi ${ }^{14}$ or "nuclear power", sold by e.g. Vattenfall ${ }^{15}$ or possibly "wave power" or "wind power from a vertical axis wind turbine" allowing for consumer awareness or preference of a potential advantage for vertical axis wind turbines (VAWT) over conventional, horizontal axis wind turbines (HAWT) [19]. 'Consumer Power' could assist in developing a domestic VAWT industry if a utility decided to start selling this specified product; Vertical Wind Power, only produced by VAWT's. The Bank Parallel proposes that any specific kind of electricity is possible to sell as long as a regular audit is conducted, as is the case here with GO:s being audited.

In the new paradigm, the act of purchasing electricity has evolved into the act of placing an order of consumption, beforehand, not specified in volume, space nor time, but specified in environmental quality i.e. what environmental impact does the chosen power production have. In parallel; one can withdraw money from one's account not knowing beforehand where, when and how much one withdraws. There is a difference in the balancing. The balancing of the bank account after a withdrawal in an ATM is immediate; the balancing of the bank account after a credit card has been used is monthly. The balancing of consumed electricity is annual or sometimes more frequent.

From an environmental point of view there is a substantial difference between Eco labeled electricity and electricity guaranteed of origin This since the 3rd generation of criteria for Good Environmental Choice Electricity e.g. demands that the power company selling the Eco labeled (Good Environmental Choice) electricity must deposit money in a fund for energy efficiency project. Therefore, when buying Eco labeled electricity from a utility the consumer also supports projects that reduce the use of (electric) energy.

\section{Results}

The proposed new perspective on electricity as a specified product on a non-monopoly market suggests that a person buying a specified kind of electricity which is audited by a third party, e.g. Eco labeled electricity, solar, hydro, wind, wave or nuclear power, can never receive any other Product Electricity. For this new paradigm to function there must be a regular audit of produced volume of kWh:s in specified power plants, e.g. windmills, hydropower stations or nuclear reactors, versus consumed volume of kWh:s by the customers buying the specified kind of the Product Electricity. In the EUsystem REDISS a Guarantee of Origin (GO) accompanies each kWh sold as specified electricity. These GO:s are being used for auditing Eco labeled electricity. The same reasoning applies to all electricity guaranteed of origin, e.g. solar power, wind power, wave power, hydro power or nuclear power. Here, the same GO:s are used for auditing. (www.reliable-disclosure.org/).

In the new paradigm the Product Electricity which is audited (electricity with GO:s) does not mix with the Product Electricity which is not audited (electricity without GO:s). Electricity with GO:s is traceable and a customer buying such a product receives that

${ }^{14}$ Pressmeddelande,Telge Energi, "Världens första elavtal med solel", 2011-11-14 ${ }^{15}$ Vattenfall's homepage, http://www.vattenfall.se/sv/teckna-elavtal.htm

Int J Earth Environ Sci

ISSN: $2456-351 \mathrm{X}$ product, no other. Which anonymous agent $(\mathrm{kWh})$ that physically delivers that specified Product Electricity is not important, just as it is not important which physical banknote you receive when you withdraw your money from your bank account. However, there must be a stable supply of power on the grid at all times and as more and more customers buy non-fossil power, less and less electricity is produced with fossil energy because less and less money is paid to producers of fossil power (Figure 5).

In a deregulated market it is the currents of money that rule and develop the power system, not the currents of electrons.

\section{BANK GRID POWER GRID}

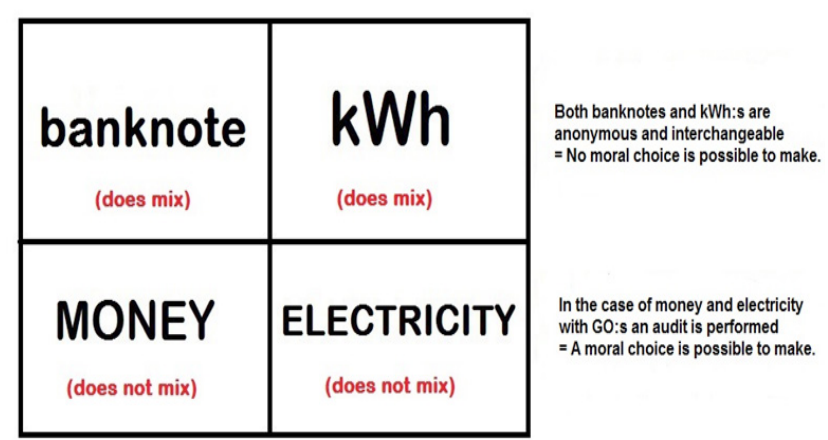

Figure 5: The pedagogical foursquare (2nd)

\section{The necessary audit}

In the new paradigm all electricity which is audited (electricity with GO:s) can be traced, hence it does not mix, whereas electricity which is not audited (electricity without GO:s) cannot be traced, hence it does mix. It is the demand for a regular audit, preferably by a third party, that allows the Product Electricity to be traced. The audit is performed by auditing the volume of $\mathrm{kWh}$ :s produced in a specified power plant complying with a set of criterion, e.g. a windmill, a wave power generator, nuclear reactor or hydro power station, versus the volume of kWh:s sold as specified electricity, e.g. Eco labeled electricity. Auditing produced kWh:s versus consumed kWh:s permits the Product Electricity to be traceable. The GO:s in the EU-system REDISS makes this auditing of electricity very straight forward.

The quote from Hauch [16];

"In Norway, $\mathrm{CO}_{2}$ emissions can be reduced only by substitution in households and in other productions sectors than electricity" reveals the common misconception. Just because the power is produced in Norway does not mean it is consumed in Norway, by Norwegians. It can equally be sold to Swedes, Finns and Danes who buy Eco labeled power. In turn, the power produced in Sweden, Finland and Denmark is bought and consumed by the Norwegian customers. The only way for a Norwegian to get his power from renewable sources of energy, e.g. Norwegian hydro power, is by buying audited electricity with GO:s, e.g. Eco labeled electricity. The Norwegian power consumers will, simply by buying Eco labeled power, or nuclear power, reduce their $\mathrm{CO}_{2}$ emissions from a level of emissions of $\mathrm{CO}_{2}$ corresponding to the Nordic Residual Mix down to zero or very close to zero [20,21].

Very few people in Sweden want to buy electricity generated from fossil fuels such as coal, oil and gas. This is true also for other countries $[22,23]$. In Hauch [16] it is stipulated that coal is successively replaced by natural (fossil) gas thus reducing the $\mathrm{CO}_{2}$ emissions. If the new 
Citation: Ribbing P (2018) On the Analogy Between the Electric Grid and Our Banking System:Investigating "Consumer Power" in Deregulated Power Markets. Int J Earth Environ Sci 3: 154. doi: https://doi.org/10.15344/2456-351X/2018/154

Page 8 of 10

paradigm is embraced by the market, coal will not be replaced by natural gas. Coal however, will be replaced by specified renewable energy or nuclear energy. No power company will invest in production of fossil power as more and more consumers actively choose not to buy fossil power. Obviously, 'Consumer Power' on Nord Pool could have a big impact on which energy sources future investments are made in.

\section{Discussion/Abstract reasoning}

The proposed parallel between the Product Electricity, transferred on the electric grid, and Money, transferred on the "bank grid", can be evaluated by an upscaling in abstraction.

When travelling abroad you can withdraw your money from your account, and receive bills of a different currency. It is still your money being withdrawn e.g. in dollar bills from an ATM in Atlanta Georgia or British pound sterling from a banking machine in London, England, even though the money deposited in your account was Swedish Crowns from your employer back home.

According to the proposed parallel between the Product Electricity and money, Eco labeled electricity from a Swedish windmill could be sold to a person living in Atlanta, Georgia. The audit would be conducted in the same manner: produced $\mathrm{kWh}$ in Sweden versus consumed kWh in Georgia and produced kWh in Georgia versus consumed kWh in Sweden. The first part signifying electricity sold from Sweden to Georgia and the second part signifying electricity sold from Georgia to Sweden. Both parties must participate, and the volumes of the specified Product Electricity bought and sold, must be equal.

However, this is only abstract reasoning to show that the proposed parallel is logically consistent. Electricity sales without the actual, physical transfer of $\mathrm{kWh}$ is highly unlikely to develop, though a common European electricity market is probable in the future. Then, on a common EU Power Exchange, Eco labeled electricity from a Swedish wave power station could be sold to a person living anywhere in Europe, e.g. London. This requires the same audit as the one being conducted today within the Nord Pool market: REDISS with Guarantees of Origins. Since electricity is balanced yearly, an annual audit would be sufficient.

\section{What products are there to choose from?}

On the Swedish electricity market there are a number of different products to choose from. The fact that there is no fossil power (with GO:s) offered as a product on the market, mirrors the popular unwillingness to buy electricity produced from fossil sources of energy. The same unwillingness to pay for fossil power, "mirrored" in the parameter "Willingness To Pay" (WTP), i.e. to pay extra for "Green Power", was found in many of the articles reviewed $[5,6,7,8]$.

There are 120 companies selling electricity in Sweden alone. The following 10 specified products are offered to the Swedish electricity consumers by the 20 largest sellers on the market, having a market share of over $85 \%$ (Table 2):

\begin{tabular}{|c|c|c|c|c|c|c|c|c|c|}
\hline Power company & $\begin{array}{l}\text { Market } \\
\text { share }\end{array}$ & $\begin{array}{l}\text { Good } \\
\text { Environmental } \\
\text { Choice (GO) }\end{array}$ & $\begin{array}{l}\text { Renewable } \\
\text { (GO) }\end{array}$ & $\begin{array}{l}\text { Hydro } \\
\text { (GO) }\end{array}$ & $\begin{array}{l}\text { Wind } \\
\text { (GO) }\end{array}$ & $\begin{array}{l}\text { Locally } \\
\text { produced } \\
\text { Renewable (GO) }\end{array}$ & $\begin{array}{l}\text { Off shore } \\
\text { Wind } \\
\text { (GO) }\end{array}$ & $\begin{array}{l}\text { Nuclear } \\
(\mathrm{GO})\end{array}$ & $\begin{array}{l}48 \% \text { Renewable } \\
52 \% \text { Nuclear } \\
\text { (GO) }\end{array}$ \\
\hline Vattenfall & $18,0 \%$ & 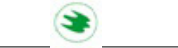 & $\mathrm{X}$ & $\mathrm{X}$ & $\mathrm{X}$ & - & - & $\mathrm{X}$ & $\mathrm{X}$ \\
\hline E.ON & $12,9 \%$ & $\leqslant$ & $\mathrm{X}$ & $\mathrm{X}$ & $\mathrm{X}$ & $\mathrm{X}$ & $\mathrm{X}$ & - & - \\
\hline Fortum & $11,9 \%$ & 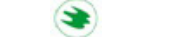 & $\mathrm{X}$ & $\mathrm{X}$ & $\mathrm{X}$ & $\mathrm{X}$ & - & - & - \\
\hline DinEl & $5,7 \%$ & $\leqslant$ & $\mathrm{X}$ & $\mathrm{X}$ & $\mathrm{X}$ & $\mathrm{X}$ & - & - & - \\
\hline Bixia & $5,6 \%$ & 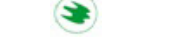 & $\mathrm{X}$ & $\mathrm{X}$ & $\mathrm{X}$ & $\mathrm{X}$ & - & - & - \\
\hline Jämtkraft & $4,4 \%$ & 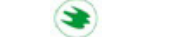 & $\mathrm{X}$ & - & $\mathrm{X}$ & - & - & - & - \\
\hline Hafslund (Norge) & $4,0 \%$ & No license & $\mathrm{X}$ & - & - & - & - & - & - \\
\hline Telge Energi & $3,2 \%$ & No license & $\mathrm{X}$ & $\mathrm{X}$ & $\mathrm{X}$ & - & - & - & - \\
\hline Mälarenergi & $3,0 \%$ & $\rightarrow$ & $\mathrm{X}$ & $\mathrm{X}$ & $\mathrm{X}$ & $\mathrm{X}$ & & - & - \\
\hline Kraftringen & $2,8 \%$ & 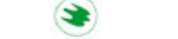 & $\mathrm{X}$ & - & - & - & - & - & - \\
\hline Öresundskraft & $2,3 \%$ & 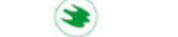 & $\mathrm{X}$ & - & - & - & - & - & - \\
\hline Skellefteå Kraft & $2,3 \%$ & $\Leftrightarrow$ & $\mathrm{X}$ & - & - & - & - & - & - \\
\hline Mölndal Energi & $1,9 \%$ & $\leqslant$ & $\mathrm{X}$ & - & - & - & - & - & - \\
\hline GodEl & $1,8 \%$ & 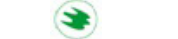 & - & - & - & - & - & - & - \\
\hline Billinge Energi & $1,0 \%$ & No license & $\mathrm{X}$ & $\mathrm{X}$ & - & - & - & - & - \\
\hline Nordic Green Energy & $1,0 \%$ & 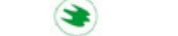 & $\mathrm{X}$ & $\mathrm{X}$ & $\mathrm{X}$ & - & - & - & - \\
\hline Umeå Energi & $1,0 \%$ & 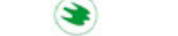 & $\mathrm{X}$ & - & - & - & - & - & - \\
\hline Energi Försälj Sverige & $0,9 \%$ & 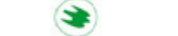 & $\mathrm{X}$ & $\mathrm{X}$ & $\mathrm{X}$ & - & - & - & - \\
\hline Jönköping Energi & $0,8 \%$ & No license & $\mathrm{X}$ & - & - & - & - & - & - \\
\hline Karlstad Energi & $0,8 \%$ & No license & $\mathrm{X}$ & - & - & - & - & - & - \\
\hline Share of Power market & $85,3 \%$ & 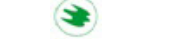 & & & & & & & \\
\hline Others & $14,7 \%$ & $\leqslant$ & & & & & & & \\
\hline
\end{tabular}

Table 2: Swedish electricity consumers by the 20 largest sellers on the market. 
1. $\quad 100 \%$ Good Environmental Choice Electricity (Bra Miljöval El)

2. $100 \%$ Renewable electricity (every company selling electricity could sell this electricity, with GO:s)

3. $100 \%$ Hydropower

4. $100 \%$ Wind power

5. $100 \%$ Renewable electricity produced locally (without any def. of what is "locally produced")

6. $100 \%$ Wind power from off-shore wind farms

7. $100 \%$ Nuclear power

8. Vattenfall own production mix $^{16}(52 \%$ nuclear, $46 \%$ hydro, $2 \%$ wind and solar)

9. $100 \%$ Solar power

10. $100 \%$ Swedish Solar power, only from Telge Energi

In addition to these 10 products there are a number of wind power cooperatives offering $100 \%$ cooperative wind power, some are Eco labeled with Good Environmental Choice, some are without the Eco label.

\section{Norway, Denmark and Finland}

According to the REDISS summary of 2014 and 2016 there are large differences between the Nordic countries in the amount of 'Untracked Consumption ${ }^{177,18}$. In the Nordic countries people are equally aware of the dangers of climate change. However, the new paradigm where electricity is a diversified product with different fossil content has not yet been largely accepted by the Norwegians, the Danes and the Finns. There has even been a ruling by the Norwegian Consumer Authority in 2010 that ruled marketing of "Green Power" illegal ${ }^{19}$. Clearly, this was a misguided ruling because it was a decision done using the traditional perspective.

Final Residual Mixes, Untracked Consumption (Electricity sold without GO:s) was in:

1. Denmark 2014: $93,94 \%$ Denmark 2016: $92,62 \%$

2. Norway 2014: $83,72 \%$ Norway 2016: $84,20 \%$

3. Finland 2014: 74,80 \% Finland 2016: $\quad 73,58 \%$

4. Sweden 2014: 27,45 \% Sweden: 2016: $16,84 \%$

\section{Conclusions and Recommendations}

On a free market the price is determined as the equilibrium of supply (S) and demand (D) curves (Figure 6).

As demand for fossil power decreases (quantity Q decreases), so does the price $(\mathrm{P})$. Power plants running on fossil energy will get less and less revenue as demand for fossil power diminishes. If (when) the price for a $\mathrm{kWh}$ of fossil power reaches a level lower than the production cost the production will halt.

Vice versa; as demand for fossil-free power increases so does the price. Power production from renewable energy sources (or nuclear) will get higher revenue as demand for fossil-free power increases. When the price for fossil-free power increases so will investments in

${ }^{16} \mathrm{https} / /$ www.vattenfall.se/elavtal/energikallor/elens-ursprung/

${ }^{17} \mathrm{http}: / /$ www.reliable-disclosure.org/upload/161-RE-DISS_2014_Residual_Mix

Results_2015-05-15_corrected2.pdf

${ }^{18} \mathrm{https} / / /$ www.grexel.com/sites/grexel.com/files/aib_2016_residual_mix_results.pdf

${ }^{19} \mathrm{http}: / /$ www.forbrukerombudet.no/asset/3759/1/3759_1.pdf

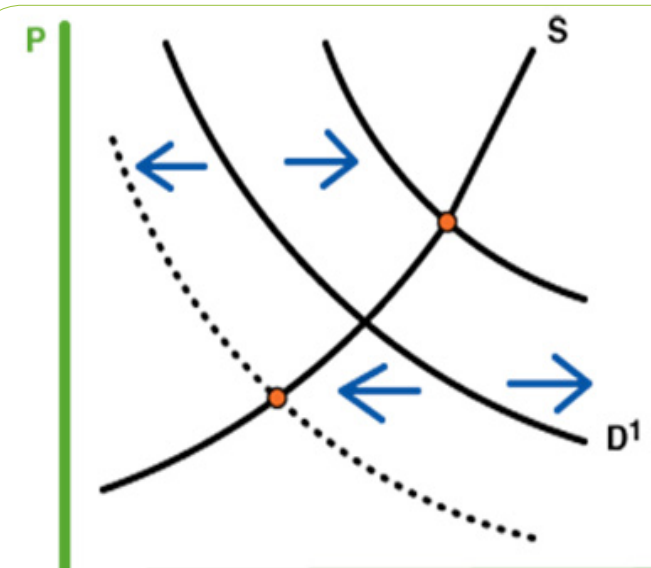

Q

Figure 6: Supply \& Demand.

fossil-free power production. The supply will then increase, and thus the price of fossil-free power will decrease. A free market produces whatever the consumers are willing to pay for. The power market is no exception to this rule. The power market could supply $100 \%$ fossilfree power, if that is what the customers choose to buy. A very large majority of customers in Sweden do not want to buy fossil power, nor do the majority of consumers in other countries trading their power on Nord Pool. Coal is a 'four-letter-word' in many countries. Possible political decisions could include such laws that require state-owned companies, national agencies, municipalities and the whole public sector to buy $100 \%$ fossil-free power.

Nord Pool could be the first Power Exchange trading $100 \%$ renewable energy. The first step in this transition could be to differentiate the exchange into two product categories; Eco labeled electricity and Nord Pool Residual Mix. This study concludes that 'Consumer Power' in deregulated electricity markets could affect major investment decisions in power companies.

\section{Recommendation to the EU}

In REDISS it is allowed to sell the GO:s without selling the electricity that the GO was "tagged" to. This has increased the popular misconception and greatly reduced the transparency and credibility of the REDISS-system. E.g. Vattenfall can sell "Solar Power" in Sweden by buying GO:s from PV production in Italy ${ }^{20}$ without actually buying that solar PV produced power. That makes the whole idea of the new paradigm suspicious. It loses credibility. My recommendation after working over 20 years with Eco labeled power, is to "glue" the GO to the Product Electricity so that no one can buy the GO without, at the same time, buy that electricity. To understand this, one has to understand the new paradigm. My hope is that this article has explained in detail how the now paradigm works and that not all power mixes on the electric grid. Only power without GO:s mixes. Power with GO:s does not mix. Only the kilowatt-hours mix. That is the new paradigm.

Recommendation to the Swedish Energy Markets Inspectorate (https://www.ei.se/en/)

Since 2013 all Baltic states trade all their power on Nord Pool ${ }^{21}$. Consequently all power from Estonia. Latvia and Lithuania should

${ }^{20} \mathrm{https} / / / \mathrm{www} . v a t t e n f a l l . s e / e l a v t a l / e n e r g i k a l l o r / e l e n s-u r s p r u n g /$ ${ }^{21}$ https://www.nordpoolgroup.com/About-us/History/ 
Citation: Ribbing P (2018) On the Analogy Between the Electric Grid and Our Banking System:Investigating "Consumer Power" in Deregulated Power Markets. Int J Earth Environ Sci 3: 154. doi: https://doi.org/10.15344/2456-351X/2018/154

be included and the "new" NRM (Nord Pool Residual Mix) calculated from all the 7 states trading at the Nord Pool power exchange: DK, NO, FI, SE, EE, LV, LT.

\section{Competing Interests}

The author declares no competing interests. The author declares that vested interests in the Fossil and Nuclear Energy industry has been actively opposing this Paradigm shift.

\section{References}

1. Arrhenius $S$ (1896) On the Influence of Carbonic Acid in the Air upon the Temperature of the Ground. Philosophical Magazine and Journal of Science 41: 237-276.

2. Lönnberg J, Bladh J (2014) Flexibility and regulation capability of hydropower systems to balance large amounts of wind power: Influence of plant properties and hydrological conditions.

3. Olauson J, Ayob MN, Bergkvist M, Carpman N, Castellucci V, et al. (2016) Net load variability in Nordic countries with a highly or fully renewable power system. Nature Energy 1: 1-8.

4. http://www.energimyndigheten.se/globalassets/statistik/overgripanderapporter/energilaget-2015_webb.pdf

5. Kristina E (2005) Public and private attitudes towards "green" electricity: the case of Swedish wind power. Energy Policy 33: 1677-1689.

6. Zoric J, Hrovatin N (2012) Household willingness to pay for green electricity in Slovenia. Energy policy 47: 180-187.

7. Wüstenhagen R, Markard J, Truffer B (2003) Diffusion of green power products in Switzerland. Energy Policy 31: 621-632.

8. Kaenzig J, Heinzle SL, Wüstenhagen R (2013) Whatever the customer wants, the customer gets? Exploring the gap between consumer preferences and default electricity products in Germany. Energy Policy 53: 311-322.

9. Morton DL (2002) Reviewing the history of electric power and electrification Endeavour 26: 60-63.

10. Kåberger $T$ (2003) Environmental labelling of electricity delivery contracts in Sweden. Energy Policy 31: 633-640.

11. http://nsninterconnector.com/

12. The concise encyclopedia of economics.

13. Batista G, Anjos MF, Vanelli A (2006) Modeling Market Power in Electricity Markets: Is the Devil Only in the Details? The Electricity Journal 20: 82-92.

14. Boylestad RL (2015) Introductory Circuit Analysis, 13th Edition.

15. Hansla A, Gamble A, Juliusson A, Gärling T (2008) Psychological determinants of attitude and willingness to pay for green electricity. Energy Policy 36: 768-774.

16. Hauch $\mathrm{J}$ (2003) Electricity trade and $\mathrm{CO} 2$ emission reductions in the Nordic countries. Energy Economics 25: 509-526.

17. Wüstenhagen R, Bilharz $M$ (34) Green energy market development in Germany: effective public policy and emerging customer demand. Energy Policy 34: 1681-1696.

18. Kriterier BM (2009) Elenergi Version.

19. Eriksson S, Bernhoff H, Leijon M (2008) Evaluation of different turbine concepts for wind power. Renewable \& Sustainable Energy Reviews 12 : 1419-1434.

20. Holttinen $\mathrm{H}$, Tuhkanen $\mathrm{S}$ (2004) The effect of wind power on $\mathrm{CO} 2$ abatement in the Nordic Countries. Energy Policy 32: 1639-1652.

21. Sjödin J, Grönkvist S (2004) Emissions accounting for use and supply of electricity in the Nordic market. Energy Policy 32: 1555-1564.

22. Zoric J, Hrovatin N (2012) Household willingness to pay for green electricity in Slovenia. Energy policy 47 (2012) 180-187.

23. Wüstenhagen R, Markard J, Truffer B (2003) Diffusion of green power products in Switzerland. Energy Policy 31: 621-632. 